\title{
The Mobile Shopping Engagement: Surveys' Review and Empirical Study
}

\author{
Eftychia Gkiolnta \\ Postgraduate Student, University of Macedonia, Thessaloniki, Greece \\ E-mail:mai1401@uom.edu.gr \\ Vaggelis Saprikis ${ }^{1}$ \\ Adjunct Senior Lecturer, Western Macedonia University of Applied Sciences, Kozani, Greece \\ E-mail:saprikis@gmail.com \\ Maro Vlachopoulou \\ Professor in Marketing Information Systems, University of Macedonia, Thessaloniki, Greece \\ E-mail:mavla@uom.gr
}

Received 8 Oktober 2017/ Revised: 7 December 2017/ Accepted: 14 December 2017/ Published online: 20 December 2017

\begin{abstract}
Mobile shopping (m-shopping) has become extremely significant for both marketing and retail selling. Despite the fact that $\mathrm{m}$-shopping has evolved into a popular alternative approach for purchasing products and services worldwide, the research regarding the extent of its adoption is still on a mediocre level and in certain countries, such as Greece, is rather limited. It is highly important to analyze and fully comprehend several factors that influence the acceptance of mobile technologies by consumers in order to motivate and support sellers' mobile strategy. The objective of this research is to approach the factors that affect m-shopping with the analysis of two categories of mobile users, those who have already been involved in m-shopping and those who have not. Specifically, this work aims to explore and explain, in an introductory way, the critical factors that tend to influence m-shopping acceptance in order to predict both the consumers' attitude towards m-shopping and their purchasing behavior via mobile devices, based on literature review and empirical survey.
\end{abstract}

JEL classification: M15, M390

Keywords: mobile shopping, innovativeness, m-shopping adoption, drivers, impediments, behavior.

\section{INTRODUCTION}

Over the past decade improvements in mobile shopping (m-shopping) have advanced amazingly and this phenomenon will certainly continue in the near future (Groß, 2015). Smartphone is doubtlessly one of the most popular tools among customers, as well as the most

Corresponding author: Tel.: 0030 2461040161. Address: Koila, 50100, Kozani, Greece 
personal one, including immediacy attributes, geolocation and extremely strong interaction (Ferri et al., 2013). Considering, therefore, the extreme growth of mobile internet browsing, which is based on the Mobile Application Store, smartphones are, with no doubt, attractive marketing channels regarding communication and sales business activities. According to Ko et al. (2009), the term "m-commerce" encompasses all the activities carried out by consumers using a wireless connection to the Internet aiming to purchase products or services (m-shopping). Although the initial idea of m-shopping is not new and has existed as a concept for years (Fenech, 2002; Jih and Lee, 2003), its popularity exploded once the technologically advanced smartphones were brought out to conquer the market around the globe. Given the fact that m-shopping is able to adapt to the purchasing will of the consumer and ultimately leads to alternative ways of selling (Nielsen, 2013; Scoop Media, 2013), it is an available tool to be used for marketing investment improvements. Clarke and Flaherty (2003) identified four characteristics of m-commerce: ubiquitous presence, convenience, location tracking and customization. Taking advantage of the unique characteristics of the mobile technology of the Internet (Fenech, 2002; Lee and Kim, 2010; Lee and Lee, 2010; Lim et al., 2006; Wu and Wang, 2006; Wong et al., 2012), companies are able to create mobile services (m-services) concerning almost every aspect of people's everyday life (Varnali and Toker, 2010). M-commerce is considered to be an expansion of electronic commerce (transactions of products, services or information), going beyond the idea of the static model of a computer/ television set, to the use of mobile devices anywhere and anytime (Clarke III, 2008). However, it must be taken into account that success in the web services cannot guarantee the success in mobile shopping.

This paper is organized into the following parts. The second section discusses useful models that can be applied to the study of $\mathrm{m}$-shopping, taking into account the previous research addressing $\mathrm{m}$-shopping issues as well as expert opinions. Considering the nature of $\mathrm{m}$-shopping, a systematic and structured approach is needed so as to guarantee the quality of any proposed m-shopping model (Levy and Ellis, 2006). Based on that, a structured approach is recommended in this paper in order to examine the quality and observe the behavior of specific factors that, according to the mentioned customer-based studies, contribute to m-shopping acceptance. Therefore, a primary research approach was applied and the survey findings are presented in the third section. The research aims to examine technological, psychological and social factors which encourage Greeks to accept mobile commerce. The findings are based on characteristics of our sample and were divided into those who have already been involved in m-shopping/are experienced in mobile shopping (adopters of $\mathrm{m}$-shopping) and those who have not yet (non-adopters of $\mathrm{m}$-shopping). The last section concludes with the implications of the study, its limitations and directions for future research.

\section{LITERATURE REVIEW}

The rapid growth of mobile shopping is related to an increasing level of customers' experience with mobile devices. Mobile-optimized websites, shopping apps and digital wallets are all based on mobile shopping activities.

Mobile apps are software applications designed to be used on smartphones, tablets and other mobile devices. They are typically available via app stores which are operated by the owners of the mobile operating system. According to Statistical Portal (Statista, 2017c) by 2020, mobile apps will generate around 189 billion U.S. dollars in revenues through app stores and in-app advertising. Some of the most popular operating system-native stores are Apple's App Store, Google Play, as well as Windows Phone Store and BlackBerry App World. As of March 2017, 2.8 million apps were running at Google Play Store and 2.2 million apps in the Apple's App Store, the two leading app stores worldwide. These statistics also provide information on the global 
number of m-commerce buyers from 2012 to 2018. In 2012, 379 million users purchased retail goods via a mobile device. This figure is measured to surpass 1 billion in 2018. It should also be noted that the global mobile commerce revenues in 2014 amounted to 184 billion U.S. dollars and are projected to reach 669 billion U.S. dollars in 2018.

These statistics (Statista, 2017b) illustrate the penetration of mobile shopping in the worldwide market during the third quarter of 2016. In the survey period, it was found that the highest percentage (46\%) is represented by internet users in Pacific Asia. M-shopping, during the fourth quarter of 2016, accounted for $20.8 \%$ of digital commerce expenditure in the U.S. and by 2020 is to account for nearly $50 \%$ of all m-shopping sales. Smartphone is the most preferable device for mobile commerce, with $70 \%$ of all mobile transactions in the United States (Statista, 2017b). As for August 2016, 49\% of global survey respondents had used a retailer's website or a mobile app to purchase via smartphone or tablet, while $11 \%$ of them stated that mobile shopping was the only tool for them to make a purchase online (Statista, 2017c). As far as the most popular retail activities worldwide via mobile phones are concerned, a total of $41 \%$ of consumers from Europe as of March 2016 used their mobile device to compare prices when shopping.

Customers frequently search for coupons themselves. Specifically, coupon apps as of May 2016 ranked among the most popular retail apps in the United States. Coupon app users expected to be able to access and save coupons as one of the core functionalities of a retail app (Statista, 2017a). About $30 \%$ of U.S. coupon users had installed apps to receive and manage coupons on their mobile device, with $13 \%$ saving them in dedicated apps such as mobile wallets. The penetration of smartphones during shopping, location-based offers and in-store deals has become an attractive tool for customers to search for new brands or products. It is apparent that daily deal sites and coupons seem to be a significant marketing tool and rank among the most likely promotional tools that affect purchase decisions of consumers in the United States. In fact, the majority of consumers connecting with brands on social media do so in an attempt to receive regular coupons and promotions. During a recent survey of U.S. consumers, it was detected that many shoppers are interested in receiving coupons when participating in loyalty programs.

Although a great deal of forecasts illustrate the huge potential of $\mathrm{m}$-commerce, insufficient literature investigates in a deep way all relevant aspects of $\mathrm{m}$-shopping. This paper, in an attempt to make the reviewing task manageable, focuses on two research streams which are referred to as "Human mobile interaction" and "Psychological, social aspects of m-shopping". So, in the following section, the literature review, which considers retail-oriented articles that take into account $\mathrm{m}$-shopping as online distribution channel for product purchase, is presented (Table 1).

Table 1

Literature Review

\begin{tabular}{|c|c|c|c|}
\hline $\begin{array}{l}\text { Literature } \\
\text { Reference }\end{array}$ & Research Objectives & $\begin{array}{l}\text { Theoretical Model } \\
\text { based on }\end{array}$ & Findings \\
\hline $\begin{array}{l}\text { Ferri et al. } \\
(2013)\end{array}$ & $\begin{array}{l}\text { The psychological, technological } \\
\text { and/or social factors in } \\
\text { acceptance of m-shopping }\end{array}$ & $\begin{array}{l}\text { M-CAM (Mobile } \\
\text { Commerce } \\
\text { Acceptance } \\
\text { Model) }\end{array}$ & $\begin{array}{l}\text { Social influence: intention to use mobile } \\
\text { technologies }\end{array}$ \\
\hline Groß (2014) & $\begin{array}{l}\text { Acceptance factors of consumers } \\
\text { in Germany with experience in } \\
\text { m-shopping }\end{array}$ & modified TAM & $\begin{array}{l}\text { Perceived enjoyment and trust } \\
\text { in the m-vendor affect the consumer's } \\
\text { intention to engage in m-shopping }\end{array}$ \\
\hline $\begin{array}{l}\text { Ha and } \mathrm{Im} \\
(2014)\end{array}$ & $\begin{array}{l}\text { Determinants of mobile coupon } \\
\text { service adoption: assessment } \\
\text { of gender difference }\end{array}$ & TAM & $\begin{array}{l}\text { Compatibility, enjoyment: stronger } \\
\text { determinants of attitudes toward mobile } \\
\text { coupon adoption than ease of use and } \\
\text { usefulness of mobile coupon services }\end{array}$ \\
\hline
\end{tabular}




\begin{tabular}{|c|c|c|c|}
\hline $\begin{array}{l}\text { Literature } \\
\text { Reference }\end{array}$ & Research Objectives & $\begin{array}{l}\text { Theoretical Model } \\
\text { based on }\end{array}$ & Findings \\
\hline $\begin{array}{l}\text { Holmes et al. } \\
\text { (2013) }\end{array}$ & $\begin{array}{l}\text { Examine attitudes, shopping } \\
\text { process involvement and } \\
\text { location in m-shopping behavior }\end{array}$ & & $\begin{array}{l}\text { Higher use of the mobile phone in the } \\
\text { information search and consideration } \\
\text { of alternative phases than in the } \\
\text { purchase transaction (higher with higher } \\
\text { involvement products) }\end{array}$ \\
\hline $\begin{array}{l}\text { Hung et al. } \\
(2012)\end{array}$ & $\begin{array}{l}\text { Determinants of m-shopping } \\
\text { continuance by incorporating } \\
\text { trust }\end{array}$ & $\begin{array}{l}\text { ECM (extended } \\
\text { Expectation- } \\
\text { Confirmation } \\
\text { Model) }\end{array}$ & $\begin{array}{l}\text { Trust: main determinant for m-shopping } \\
\text { continuance }\end{array}$ \\
\hline
\end{tabular}

Khajehzadeh The roles of shopping motivation

et al. (2014) and regulatory fit in consumer responses to mobile coupons

Lu (2014) The impact of personal innovativeness in information technology (PIIT) and social influence on user continuance intention toward m-shopping in the USA

San-Martín Types of mobile shoppers that et al. (2013) show different profiles based on their perception about drivers and impediments
TAM

(Technology

Acceptance

Model)
San-Martín The impact of age in the et al. (2015) generation of satisfaction and WOM in m-shopping

Wang et al. The role of $\mathrm{m}$ - shopping (2015) in affecting Customer Purchase Behavior

Yang (2010) Critical determinants of US consumers' intentions to use mobile shopping services
UTAUT (the Unified Theory of Acceptance and Use of Technology)

TPB (Theory of Planned Behavior)
Hedonic shoppers redeem a wider variety of offers than utilitarian shoppers

Personal innovativeness, perceived usefulness, social influence: determinants of user continuance intention

Three types of mobile shoppers: thoughtful, motivated, reluctant

Perceived entertainment: higher importance for young adults Subjective norms: crucial for adults Low-spending customers: both their order rate and order size increase as they become accustomed to m-shopping

Utilitarian and hedonic performance expectancy, social influence, facilitating conditions: critical determinants of US consumers' intentions to use m-shopping services

Yang (2012) Consumer technology traits in determining $\mathrm{m}$-shopping adoption (technology self-efficacy, technology innovativeness, level of experience of use)

Yang and If consumers' levels $\begin{array}{ll}\text { Forney } & \text { of technology anxiety moderate } \\ \text { (2013) the causal relationships among }\end{array}$ (2013) the causal relationships amon
determinants of m-shopping adoption

Zhong (2013) Factors influencing the adoption of mobile phone shopping

\section{UTAUT}

Perceived enjoyment: the strongest determinant creating a favorable attitude toward mobile shopping adoption 


\subsection{Human Mobile Interaction}

San-Martín et al. (2015) conducted research whose objective was to provide an understanding of how the perception about drivers and impediments shared by the commercial audience of mobile shoppers their level of acceptance of $\mathrm{m}$-shopping. Based on the three types of $\mathrm{m}$-shopping (thoughtful, motivated, reluctant), on predetermined motives (convenience, company performance, marketing) and on impediments (lack of interpersonal relations, problems using the mobile device, transaction costs, and barriers to the products), the researchers reached the following conclusions regarding potential $\mathrm{m}$-shopping users: thoughtful $\mathrm{m}$-shoppers consider both utility and positive attitude important in order to have a strong will to m-shop. Motivated m-shoppers mostly appreciate drivers of a different nature (m-vendors, mix-marketing, the product and the mobile channel itself). On the other hand, reluctant $m$-shoppers are described as inexperienced or unprepared to proceed to m-shopping due to transaction costs and the lack of interpersonal relations when using mobile devices. As illustrated in Yang's research (2012), the three consumers' characteristics (technology self-efficacy, technology innovativeness, and level of experience of use) - based on the extensive TPB model - are considered to be of utmost importance in terms of how they affect consumers' attitude towards m-shopping adoption. Through the use of Structural Equation Modeling (SEM), 323 respondents were analyzed in research which was addressed to undergraduate and postgraduate students using mobile phones in the University of Texas (Lu, 2014). The variables of perceived usefulness and of personal innovativeness of the users are the factors that primarily define the consumers' attitude towards m-shopping. According to the findings of Wang et al. (2015), the adoption of m-shopping practices leads to a yearly rise in the orders rate. In addition, it is highlighted that mobile devices provide the customers with convenience and accessibility, a fact that increases spending and develops a habit of interacting with the businesses that offer a mobile channel to their clients. However, according to the research of Holmes et al. (2013) on consumers in the United Kingdom, people seem to use their mobile phones more for activities prior to purchasing, such as looking up for information, checking availability or searching for discount coupons even when it comes to lower involvement products, for example powder or bread. On the other hand, the decision-making process seems to be higher for higher involvement products, such as TVs and phones. It is indicated, lastly, that the most common location for m-shopping purchases is the users' residences.

\subsection{Psychological and Social Aspects of M-Shopping}

The extant literature focuses on understanding factors affecting mobile shoppers' engagement through their effect on behavioral intention mostly based on behavioral intention theories. San-Martín et al. (2015) carried out research on 447 Spanish m-buyers. The research extensively examined the variables of perceived entertainment and subjective norms to measure the purchase intention for m-shopping and the consumers' tendency to adopt m-shopping practices (word-of-mouth), for different age groups (young adults under 25 and adults over 25). The research concluded that these two variables positively influence the sample's attitude. The study conducted by Ferri et al. (2013) based on two methods (in-depth interviews and Open Space Technology) showed that the main and initial step that motivated consumers to m-shop is social influence, accompanied by other motives such as: curiosity, image and fashion; a variable which is particularly influential among younger people. Furthermore, in research carried out by Yang (2012), the subjective norm and the behavioral control appeared to be significant defining factors for the adoption of $\mathrm{m}$-shopping practices and for the attitude towards $\mathrm{m}$-shopping. Zhong (2013) carried out research based on the TPB model by questionnaire and Structural Equation Modeling (SEM) combined with Partial Least Squares (PLS), bringing similar results. According to the research, other critical factors that influence the adoption of $\mathrm{m}$-shopping are satisfaction with the 
information system, cost of services, innovativeness, perceived enjoyment, peer influence, selfefficacy and attitude.

Using a modified model of analysis TAM, the research of Groß (2014) showed that perceived enjoyment and trust in mobile vendors influence consumers' intention to participate in $\mathrm{m}$-shopping. It is this intention, though, that defined m-shopping behavior as a whole. Finally, as far as intended behavior of $\mathrm{m}$-shoppers is concerned, the research showed that both attitude towards $\mathrm{m}$-shopping and trust in m-vendors are highly important and positive prognostic factors. Hung's (2012) research reached similar conclusions. For the study realized by Kumar and Mukherjee (2013) an integrated approach was adopted, combining TAM and TRI in order to predict attitudes towards $\mathrm{m}$-shopping and purchasing behavior via mobile devices. The research concluded that optimism, innovativeness and security have a direct impact on consumers' perceptions and an indirect impact on their attitude and intention to engage in m-shopping. The online research carried out by Yang and Forney (2013) was supported by a sample of 400 users of mobile services and applied the modified model UTAUT (Unified Theory of User Acceptance and Use of Technology). According to the findings of the research, the influence of the facilitating conditions, both on utilitarian and hedonic performance expectancy, is stronger for consumers with a lower level of technology anxiety as opposed to those with a higher level. Ha and Im's (2014) research showed that, in general, compatibility and enjoyment are more important defining factors than convenience in use and usefulness of mobile services, when it comes to consumers' attitudes towards mobile coupons adoption. Finally, the findings of the research carried out by Khajehzadeh et al. (2014) showed that buyers with hedonic motives respond to products of both utilitarian and hedonic nature, regardless of whether the offer is congruent or not to their current or future needs. On the contrary, buyers with rather utilitarian motives tend to prefer products of utilitarian nature and offers that respond to their current needs.

\section{DATA AND METHODS}

The objective of this research is to investigate the factors that affect $\mathrm{m}$-shopping with the analysis of two categories of mobile users, those who have already been involved in m-shopping and those who have not.

The purpose of this paper is to add knowledge on customer m-shopping behavior through comparing the two shopper segments' (mobile shoppers and non-mobile shoppers) driving motivations. Non-mobile customers could be also characterized as potential $\mathrm{m}$-shoppers by considering the increased functionality offered by smartphones that brings out significant potential for the development of retailing through mobile channels. Specifically, this work aims to predict both the consumers' attitude towards m-shopping and their purchasing behavior via mobile devices.

It is impossible to neglect the fact that customer needs, wishes and behaviors towards Internet shopping strongly differ among different countries. Consumer culture has become one of the most powerful traits that is able to affect both individual and group decisions. The characteristics of Greeks seem to be unique, due to the disability of the country to implement an independent monetary policy because of its accession to the euro zone (Duquenne and Vlontzos, 2014; Vlamis, 2014).

The ongoing economic crisis in Greece has a direct negative impact on basic goods, such as food consumption, with a statistically smaller average decrease in per month food expenses (Duquenne and Vlontzos, 2014). Since the year 2010, the implementation of strict austerity programs has been causing a considerable decrease in demand for goods and services, including also the Greek property market (Vlamis, 2014). Over time, fewer Greek consumers would be willing to buy ecological products if these were not comparable enough with the conventional 
products in terms of price and efficacy, because they were rated to be negatively influenced by environmental-unconcern attitudes as well as materialism (Tilikidou and Delistaurou, 2014).

However, Greece nowadays seems to be in a transitional period. The former images, beliefs as well as points of view are a critical factor that is closely related to our consumer behavior as citizens of Greece.

It should be noted that the increasing westernization of Greece in the last decades was responsible for a change in Greek people's habits (Kearny, 2010). In the food sector (Tsourgiannis et al., 2014), the health issues, price, governmental and cultural factions, consumers' demographic characteristics, distribution channels as well as the dominance of supermarket chains also affect customers' buying behavior within EU countries (Kotler, 1994; Tsourgiannis, 2008; Tsourgiannis et al., 2014). Moreover, religious prohibitions and countercultural attitudes play a significant role in Greek customers' purchasing decisions concerning products, including the size of the family (Michalopoulos and Demoussis, 2001).

We have to take under serious consideration that mainly two following characteristics of an Internet retail store are rated by Greek customers as high-value (Vrechopoulos et al., 2001). Firstly, information and price comparisons among alternative products, such as information about product prices, costs, product traits, corporate image, product comparisons using alternative factors which facilitate consumer product comparisons are based on customers' experience from previous use, evaluations for the final choice (Papafotikas et al., 2013). Secondly, quick access to the store's web site. The loyal Greek consumer tends to consider factors such as product image, compatibility with the current lifestyle (way of life), social environment, product features, previous experience and quality.

Furthermore, the cognitive dimension of product involvement and impulsiveness affect purchase intensions in Greece (Drossos et al., 2014). SMS advertising could not be recommended for all types of products, especially when we are referring to high levels of involvement. On the other hand, in low involvement products, especially when targeted to high impulse buying consumers, SMS is able to increase purchase intention.

The present research is descriptive in nature as apart from descriptive statistics, only the non-parametric Mann-Whitney U test was applied to statistically compare Greek consumers' perceptions towards m-commerce.

Data was collected by means of an electronic questionnaire administered from February to April 2015 via e-mailing lists and two popular social networks: Facebook and Twitter. Concerning the measurement items, they were designed on the basis of a comprehensive literature review and prior scientific surveys approved for their validity and reliability. Prior to its distribution, all measurement items were pretested. Specifically, two academics and two practitioners reviewed the questions to ascertain the precision of the instructions and the content validity. Moreover, a pilot test using a sample of fifteen students helped to identify possible problems in terms of clarity and accuracy. Thus, a number of changes were made to improve the presentation of the items, based on comments and feedback.

The questions used in the questionnaire were mainly closed-ended, as they contribute to the structure of the questionnaire and they eliminate the danger of bias (Dillman, 2007). The first three questions of the questionnaire are ordinal, since the participants are expected to answer "Not at All" (1) to "To a Large Extent" (5) based on a 5-point Likert scale. These questions record the preferences of the sample, such as: use of smartphone (q. SM1), tablet (q. TBL2), and mobile internet (q.MI3). The fourth question is the only exception, as it is independent and nominal (Msh4) "Have you purchased any product/service via mobile devices?", representing the current preference of the sample concerning m-shopping (see Table 2). The next group of questions covers the critical $\mathrm{m}$-shopping variables according to international literature. These questions are ordinal since the respondents are requested to answer "Strongly Disagree" (1) to "Strongly Agree" (5) based on a 5-point Likert scale (Gehrt and Carter, 1992). The categorization of the 
questions, which are present in detail in Table 2, is based on technical, psychological and social parameters. The last group of questions covers the demographic data of the participants, such as sex and profession (nominal variables) as well as age, level of education and monthly income (ordinal).

Table 2

Variables and individual items of the questionnaire based on the literature

\begin{tabular}{|c|c|c|c|}
\hline Variable & Indicators & Measurement items & $\begin{array}{l}\text { Literature } \\
\text { Reference }\end{array}$ \\
\hline & SM1 & To which extent do you use smartphones? & \\
\hline & TBL2 & To which extent do you use tablets? & \\
\hline & MI3 & $\begin{array}{l}\text { To which extent do you use mobile internet (use of the internet } \\
\text { on mobile devices, such as mobile phones and tablets)? }\end{array}$ & \\
\hline & MSh4 & Have you purchased products/ services via mobile devices? & \\
\hline \multirow[t]{4}{*}{$\begin{array}{l}\text { Perceived ease } \\
\text { of use }\end{array}$} & PEU1 & $\begin{array}{l}\text { The use of mobile devices for purchasing products/ services is } \\
\text { easy. }\end{array}$ & \multirow{4}{*}{$\begin{array}{l}\text { Kumar } \\
\text { and Mukherjee, } \\
2013 \text {; } \\
\text { Yang, 2010; } \\
\text { Karaatli et al., } \\
2010\end{array}$} \\
\hline & PEU2 & $\begin{array}{l}\text { It is easy to learn how to purchase products/ services via mobile } \\
\text { devices. }\end{array}$ & \\
\hline & PEU3 & $\begin{array}{l}\text { You can find exactly what you want to purchase via mobile } \\
\text { devices. }\end{array}$ & \\
\hline & PEU4 & $\begin{array}{l}\text { It is easy to become skilled in using mobile devices to purchase } \\
\text { products/ services. }\end{array}$ & \\
\hline \multirow{5}{*}{$\begin{array}{l}\text { Perceived } \\
\text { Usefulness }\end{array}$} & PU1 & M-shopping is time-saving (faster transactions). & \multirow{5}{*}{$\begin{array}{l}\text { Hung et al., } \\
\text { 2012; Karaatli } \\
\text { et al., } 2010\end{array}$} \\
\hline & PU2 & M-shopping transactions are more efficient. & \\
\hline & PU3 & $\begin{array}{l}\text { Products/ services are cheaper when purchased via mobile } \\
\text { devices. }\end{array}$ & \\
\hline & PU4 & Generally, m-shopping is more pleasant. & \\
\hline & PU5 & M-shopping improves productivity. & \\
\hline \multirow[t]{4}{*}{ Trust } & TR1 & Money transactions are safe. & \multirow{4}{*}{$\begin{array}{l}\text { Kumar and } \\
\text { Mukherjee, } \\
\text { 2013; Hung } \\
\text { et al., 2012; } \\
\text { Groß, 2014; } \\
\text { Karaatli et al., } \\
2010\end{array}$} \\
\hline & TR2 & Personal data are preserved. & \\
\hline & TR3 & Terms and conditions of the transactions are observed. & \\
\hline & TR4 & The outcome of the transactions will meet my expectations. & \\
\hline \multirow[t]{4}{*}{ Innovativeness } & IN1 & $\begin{array}{l}\text { In relation to my friends, I would be one of the first to use } \\
\text { mobile devices in order to purchase products/ services. }\end{array}$ & \multirow{4}{*}{$\begin{array}{l}\text { Kumar and } \\
\text { Mukherjee, } \\
\text { 2013; Lu, } 2014\end{array}$} \\
\hline & IN2 & I like getting updated about new technologies. & \\
\hline & IN3 & I like trying and experimenting with new technologies. & \\
\hline & IN4 & $\begin{array}{l}\text { My surroundings, friends and relatives ask for my advice about } \\
\text { new technologies. }\end{array}$ & \\
\hline \multirow[t]{3}{*}{ Anxiety } & AN1 & I am reluctant to purchase products/ services via mobile devices. & \multirow{3}{*}{$\begin{array}{l}\text { Yang } \\
\text { and Forney, } \\
2013\end{array}$} \\
\hline & AN2 & $\begin{array}{l}\text { I hesitate to purchase products/ services via mobile devices } \\
\text { because I am afraid of making a mistake. }\end{array}$ & \\
\hline & AN3 & I find $\mathrm{m}$-shopping intimidating in some way. & \\
\hline
\end{tabular}




\begin{tabular}{|c|c|c|c|}
\hline Variable & Indicators & Measurement items & $\begin{array}{l}\text { Literature } \\
\text { Reference }\end{array}$ \\
\hline \multirow[t]{3}{*}{$\begin{array}{l}\text { Mobile } \\
\text { Skillfulness }\end{array}$} & MS1 & $\begin{array}{l}\text { I am certain that I can purchase a product/service via mobile } \\
\text { devices effectively. }\end{array}$ & \multirow[t]{3}{*}{ Yang, 2012} \\
\hline & MS2 & $\begin{array}{l}\text { I believe that I am in the position to purchase a product/service } \\
\text { via a mobile device soon if I get a little help. }\end{array}$ & \\
\hline & MS3 & $\begin{array}{l}\text { I believe that I am in the position to purchase a product/service } \\
\text { via a mobile device soon provided I have used the device before. }\end{array}$ & \\
\hline \multirow[t]{3}{*}{ Perceived Risk } & PR1 & M-shopping is secure. & \\
\hline & PR2 & $\begin{array}{l}\text { If I purchase products/ services via mobile devices, there is no } \\
\text { danger of any problem to occur. }\end{array}$ & \\
\hline & PR3 & $\begin{array}{l}\text { The electronic shops where I can purchase products/ services are } \\
\text { secure. }\end{array}$ & \\
\hline \multirow{3}{*}{$\begin{array}{l}\text { Perceived } \\
\text { Enjoyment }\end{array}$} & PE1 & I believe that m-shopping is enjoyable. & \multirow{3}{*}{$\begin{array}{l}\text { Hung et al., } \\
\text { 2012; Yang, } \\
2012\end{array}$} \\
\hline & PE2 & I believe that m-shopping gives pleasure. & \\
\hline & PE3 & I believe that $\mathrm{m}$-shopping is entertaining. & \\
\hline \multirow[t]{10}{*}{$\begin{array}{l}\text { Relationship } \\
\text { drivers }\end{array}$} & RD1 & $\begin{array}{l}\text { The reward with loyalty points for purchasing products/ services } \\
\text { via mobile devices. }\end{array}$ & \multirow{10}{*}{$\begin{array}{l}\text { Ha and } \\
\text { Im, 2014; } \\
\text { Khajehzadeh } \\
\text { et al., } 2014\end{array}$} \\
\hline & RD2 & $\begin{array}{l}\text { The provision and redemption of coupons when it comes to } \\
\text { purchases via mobile devices. }\end{array}$ & \\
\hline & RD3 & $\begin{array}{l}\text { Special offers/discounts valid exclusively for purchases } \\
\text { via a mobile phone or tablet. }\end{array}$ & \\
\hline & RD4 & The notifications I receive regarding the time and my location. & \\
\hline & RD5 & $\begin{array}{l}\text { I spend a lot of time on purchasing products/ services via mobile } \\
\text { devices. }\end{array}$ & \\
\hline & RD6 & M-shopping is an important part of my daily life. & \\
\hline & RD7 & $\begin{array}{l}\text { On an emotional level, I have a good relationship with } \\
\text { m-shopping. }\end{array}$ & \\
\hline & RD8 & M-shopping helps me show who I am. & \\
\hline & RD9 & M-shopping reflects my personal values. & \\
\hline & RD10 & Other people relate $\mathrm{m}$-shopping to me. & \\
\hline \multirow[t]{4}{*}{$\begin{array}{l}\text { Behavioral } \\
\text { Intention }\end{array}$} & BI1 & $\begin{array}{l}\text { I intend to purchase products/ services via mobile devices in the } \\
\text { near future. }\end{array}$ & \multirow{4}{*}{$\begin{array}{l}\text { Hung et al., } \\
\text { 2012; Yang, } \\
\text { 2010; San- } \\
\text { Martín et al., } \\
2015\end{array}$} \\
\hline & BI2 & $\begin{array}{l}\text { I believe that my interest in m-shopping is going to increase } \\
\text { in the near future. }\end{array}$ & \\
\hline & BI3 & $\begin{array}{l}\text { I intend to purchase products/ services via mobile } \\
\text { devices as often as possible. }\end{array}$ & \\
\hline & BI4 & $\begin{array}{l}\text { I am willing to persuade other people to purchase products/ } \\
\text { services via mobile devices. }\end{array}$ & \\
\hline \multirow[t]{3}{*}{$\begin{array}{l}\text { Subjective } \\
\text { norm }\end{array}$} & SN1 & $\begin{array}{l}\text { The people around me who influence my behavior believe that I } \\
\text { should purchase products/ services via mobile devices. }\end{array}$ & \multirow[t]{3}{*}{ Yang, 2010} \\
\hline & SN2 & $\begin{array}{l}\text { I should purchase products/ services via mobile devices, like my } \\
\text { friends/my surroundings. }\end{array}$ & \\
\hline & SN3 & $\begin{array}{l}\text { The people who are important to me believe that I should } \\
\text { purchase products/ services via mobile devices. }\end{array}$ & \\
\hline \multirow[t]{4}{*}{ Attitude } & AT1 & M-shopping is a good idea. & \multirow{4}{*}{$\begin{array}{l}\text { Hung et al., } \\
2012 \text {; Yang, } \\
2010\end{array}$} \\
\hline & AT2 & I am in favor of m-shopping. & \\
\hline & AT3 & M-shopping is a clever idea. & \\
\hline & AT4 & I have a positive attitude towards m-shopping. & \\
\hline
\end{tabular}


Specifically, a total of 473 respondents constituted the total sample of the survey (Table 3 ). 208 of them had an m-shopping experience (adopters) in the past, while the remaining 265 had not a related experience (non-adopters) (Table 3). More particularly, women seem to be less familiar with m-shopping (51.3\%) compared to men. As far as age groups are concerned, young adults between 18 and 24 seem to be the least experienced in m-shopping (55.1\%). Adults between 25 and 34 were the respondents who showed a rather positive attitude towards m-shopping $(91 \%)$.

Experienced $\mathrm{m}$-shopping users almost always use a smartphone (65.9\%) and almost never a tablet (33.7\%). On the other hand, non-experienced m-shopping users are much more conservative about systematically using a smartphone (32.1\%), and use a tablet even less often $(4.9 \%)$. Using the internet is clearly a more familiar practice to adopters of m-shopping compared to the rest of the sample (55.3\%). The analysis of the level of education shows that only the percentage $(23.1 \%)$ of postgraduate adopters outmatched the respective percentage of nonadopters. As far as the respondents' profession is concerned, private sector employees are ahead in $\mathrm{m}$-shopping experience $(24.6 \%)$, compared to the rest of the participants. Finally, the majority of the group of adopters of m-shopping belong to the higher level of income group (more than $1200 €$ monthly).

Table 3

Demographic characteristics of the sample

\begin{tabular}{|c|c|c|c|c|}
\hline \multirow{2}{*}{ Demographic Profile } & \multicolumn{2}{|c|}{ Adopters of mobile shopping } & \multicolumn{2}{|c|}{ Non-adopters of mobile shopping } \\
\hline & No & $\%$ & No & $\%$ \\
\hline \multicolumn{5}{|l|}{ Gender } \\
\hline Male & 104 & $50 \%$ & 129 & $48.7 \%$ \\
\hline Female & 104 & $50 \%$ & 136 & $51.3 \%$ \\
\hline \multicolumn{5}{|l|}{ Age } \\
\hline $18-24$ & 90 & $43.3 \%$ & 146 & $55.1 \%$ \\
\hline $25-34$ & 91 & $43.8 \%$ & 88 & $33.2 \%$ \\
\hline $35-44$ & 20 & $9.6 \%$ & 25 & $9.4 \%$ \\
\hline $45-55$ & 7 & $3.4 \%$ & 6 & $2.3 \%$ \\
\hline \multicolumn{5}{|l|}{ Usage of Smartphone } \\
\hline Not at all & 8 & $3.8 \%$ & 24 & $9.1 \%$ \\
\hline Rarely & 5 & $2.4 \%$ & 24 & $9.1 \%$ \\
\hline Every once in a while & 17 & $8.2 \%$ & 56 & $21.1 \%$ \\
\hline Sometimes & 41 & $19.7 \%$ & 76 & $28.7 \%$ \\
\hline Almost always & 137 & $65.9 \%$ & 85 & $32.1 \%$ \\
\hline \multicolumn{5}{|l|}{ Usage of tablet } \\
\hline Not at all & 70 & $33.7 \%$ & 144 & $54.3 \%$ \\
\hline Rarely & 43 & $20.7 \%$ & 61 & $23.0 \%$ \\
\hline Every once in a while & 35 & $16.8 \%$ & 29 & $10.9 \%$ \\
\hline Sometimes & 31 & $14.9 \%$ & 18 & $6.8 \%$ \\
\hline Almost always & 29 & $13.9 \%$ & 13 & $4.9 \%$ \\
\hline \multicolumn{5}{|l|}{ Usage of Mobile Internet } \\
\hline Not at all & 2 & $1.0 \%$ & 19 & $7.2 \%$ \\
\hline
\end{tabular}




\begin{tabular}{|c|c|c|c|c|}
\hline \multirow{2}{*}{ Demographic Profile } & \multicolumn{2}{|c|}{ Adopters of mobile shopping } & \multicolumn{2}{|c|}{ Non-adopters of mobile shopping } \\
\hline & No & $\%$ & No & $\%$ \\
\hline Rarely & 8 & $3.8 \%$ & 30 & $11.3 \%$ \\
\hline Every once in a while & 27 & $13.0 \%$ & 68 & $25.7 \%$ \\
\hline Sometimes & 56 & $26.9 \%$ & 67 & $25.3 \%$ \\
\hline Almost always & 115 & $55.3 \%$ & 81 & $30.6 \%$ \\
\hline \multicolumn{5}{|l|}{ Educational level } \\
\hline Primary & 1 & $0.5 \%$ & 2 & $0.8 \%$ \\
\hline Secondary & 34 & $16.3 \%$ & 63 & $23.8 \%$ \\
\hline Graduate & 125 & $60.1 \%$ & 154 & $58.1 \%$ \\
\hline postgraduate & 48 & $23.1 \%$ & 46 & $17.4 \%$ \\
\hline \multicolumn{5}{|l|}{ Profession } \\
\hline Student & 99 & $47.6 \%$ & 157 & $59.2 \%$ \\
\hline Private employee & 55 & $26.4 \%$ & 47 & $17.7 \%$ \\
\hline State employee & 18 & $6.8 \%$ & 24 & $9.1 \%$ \\
\hline Professional & 16 & $7.7 \%$ & 18 & $6.8 \%$ \\
\hline Unemployed & 12 & $5.8 \%$ & 13 & $4.9 \%$ \\
\hline Other & 8 & $3.8 \%$ & 6 & $2.3 \%$ \\
\hline \multicolumn{5}{|l|}{ Monthly Income } \\
\hline$<600 €$ & 80 & $38.5 \%$ & 118 & $44.5 \%$ \\
\hline $601-900 €$ & 32 & $15.4 \%$ & 27 & $10.2 \%$ \\
\hline $901-1200 €$ & 21 & $10.1 \%$ & 18 & $6.8 \%$ \\
\hline $1201-1500 €$ & 19 & $9.1 \%$ & 13 & $4.9 \%$ \\
\hline $1501-2000 €$ & 1 & $0.5 \%$ & 5 & $1.9 \%$ \\
\hline$>2000 €$ & 13 & $6.3 \%$ & 3 & $1.1 \%$ \\
\hline No answer & 42 & $20.2 \%$ & 81 & $30.6 \%$ \\
\hline
\end{tabular}

\section{RESULTS}

In this part, the findings of the research are analyzed through the presentation of the correlation control of the variables in question based on the independent variable that is processed by the nonparametric Mann-Whitney U test.

\section{Consumers' experience in mobile shopping}

The findings of the implementation of the Mann-Whitney U test in the cases where the independent variable is the question: "Have you purchased products/ services via mobile devices?" are presented. The introductory variables concerning the frequency of the use of mobile devices and the internet are first outlined (Table 4). Afterwards, there is the analysis of all the items of dependent variables regarding the technical (Table 5) and psychographic (Tables 6 and 7) aspects of $\mathrm{m}$-shopping respectively. The main axis of the research is the separation of non-adopters (Group 1) from adopters (Group 2). 
The correlation control of the factors regarding the intention to purchase products/services using m-shopping, based on the variable: "Have you purchased products/ services via mobile devices?", showed considerable differences between the two groups for the following selection factors:

Table 4

Mann-Whitney U test (Independent variable: Have you purchased products/services via mobile devices?; dependent: smartphone, tablet, mobile internet, m-shopping)

\begin{tabular}{|c|c|c|c|c|c|}
\hline \multirow[b]{2}{*}{ 1. Variables } & \multirow[b]{2}{*}{ 2. Group } & \multirow[b]{2}{*}{ 3. Mean Rank } & \multicolumn{3}{|c|}{ 4. Test Statistics } \\
\hline & & & Mann-Whitney U & $\mathrm{Z}$ & $\begin{array}{c}\text { Asymp. Sig. } \\
\text { (2-tailed) }\end{array}$ \\
\hline \multirow{2}{*}{ SM1 } & 1 & 198.08 & \multirow{2}{*}{17247.500} & \multirow{2}{*}{-7.462} & \multirow{2}{*}{.000} \\
\hline & 2 & 286.58 & & & \\
\hline \multirow{2}{*}{ TBL2 } & 1 & 207.96 & \multirow{2}{*}{19864.500} & \multirow{2}{*}{-5.521} & \multirow{2}{*}{.000} \\
\hline & 2 & 274.00 & & & \\
\hline \multirow{2}{*}{ MI3 } & 1 & 202.22 & \multirow{2}{*}{18342.500} & \multirow{2}{*}{-6.575} & \multirow{2}{*}{.000} \\
\hline & 2 & 281.31 & & & \\
\hline
\end{tabular}

The above table (Table 4) of nonparametric control presents the fact that $p$-value differs according to the positive or negative response of the sample concerning $\mathrm{m}$-shopping when it comes to the degree of the use of smartphones (SM1), tablets and the internet (MI3) ( $p$-value $<0.05$ in all cases). The participants with the positive attitude towards m-shopping experience (Group 2) exhibit higher percentages of the use of smartphones, tablets and the internet, compared to the rest of the sample, because of their higher mean position for the variables in question.

According to the findings presented in Table 5, there is an important statistical difference, first of all in the variables of perceived ease of use (F1) and perceived usefulness (F2) through all the individual items ( $p$-value $<0.05$ in all cases). To be more precise, in comparison to the whole sample, experienced m-shoppers (Group 2) strongly confirm points such as the ease of use, learning and skillfulness for purchasing via mobile devices due to their higher mean position. The group of the active m-shopping users responds more positively compared to the rest in regard to time saving (PU1), ease of transactions (PU2), usefulness (PU3), more economic purchases via mobile devices (PU4) and improvement of productivity (PU5), because of their higher mean position. Taking into consideration higher values of mean positions for each group, it is obvious that active m-shopping users appear to be much more confident about activities related to mobile markets, which refers to the variable of mobile skillfulness (F3) (p-value $<0.05$ in all cases). Based on the correlation control, the results are similar for the variable of innovativeness (F4) in using mobile devices for purchasing products and services ( $p$-value $<0.05$ in all cases). The mean position of active m-shopping users (Group 2) is definitely higher compared to Group 1 on all accounts (experimenting, trying new technologies, etc.), having, thus, the highest percentages. The mentioned results seem to be confirmed by previous empirical studies conducted by Chen (2013), Groß (2014), Wang et al. (2015) and Lu (2014). 
Table 5

Mann-Whitney U test (Independent variable: Have you purchased products/ services via mobile devices?; dependent: technical m-shopping variables)

\begin{tabular}{|c|c|c|c|c|c|c|}
\hline \multirow[b]{2}{*}{ Variables } & \multirow[b]{2}{*}{ Items } & \multirow[b]{2}{*}{ Group } & \multirow[b]{2}{*}{ Mean Rank } & \multicolumn{3}{|c|}{ Test Statistics } \\
\hline & & & & Mann-Whitney U & $\mathbf{Z}$ & $\begin{array}{l}\text { Asymp. Sig. } \\
\text { (2-tailed) }\end{array}$ \\
\hline \multirow{8}{*}{$\begin{array}{l}\text { F1 } \\
\text { Perceived Ease of Use }\end{array}$} & \multirow{2}{*}{ PEU1 } & 1 & 193.48 & \multirow{2}{*}{16027.000} & \multirow{2}{*}{-8.578} & \multirow{2}{*}{.000} \\
\hline & & 2 & 292.45 & & & \\
\hline & \multirow{2}{*}{ PEU2 } & 1 & 217.38 & \multirow{2}{*}{22361.500} & \multirow{2}{*}{-4.051} & \multirow{2}{*}{.000} \\
\hline & & 2 & 261.99 & & & \\
\hline & \multirow{2}{*}{ PEU3 } & 1 & 220.51 & \multirow{2}{*}{23190.500} & \multirow{2}{*}{-3.195} & \multirow{2}{*}{.001} \\
\hline & & 2 & 258.01 & & & \\
\hline & \multirow{2}{*}{ PEU4 } & 1 & 225.91 & \multirow{2}{*}{24620.500} & \multirow{2}{*}{-2.277} & \multirow{2}{*}{.023} \\
\hline & & 2 & 251.13 & & & \\
\hline \multirow{10}{*}{$\begin{array}{l}\text { F2 } \\
\text { Perceived Usefulness }\end{array}$} & \multirow{2}{*}{ PU1 } & 1 & 215.66 & \multirow{2}{*}{21904.000} & \multirow{2}{*}{-4.034} & \multirow{2}{*}{.000} \\
\hline & & 2 & 264.19 & & & \\
\hline & \multirow{2}{*}{ PU2 } & 1 & 217.95 & \multirow{2}{*}{22511.000} & & \\
\hline & & 2 & 261.27 & & -5.129 & .000 \\
\hline & PU 3 & 1 & 225.73 & & 100 & \\
\hline & 105 & 2 & 251.36 & 24512.500 & -2.100 & .000 \\
\hline & & 1 & 209.55 & & & \\
\hline & 104 & 2 & 271.98 & 20203.000 & -3.174 & .000 \\
\hline & PU 5 & 1 & 211.78 & 20878000 & 1872 & \\
\hline & 100 & 2 & 269.13 & $200 / 0.000$ & -4.012 & .000 \\
\hline & PD 1 & 1 & 204.05 & & 5.431 & \\
\hline & 1 & 2 & 278.98 & 20130.500 & -3.451 & .000 \\
\hline F3 & PR2 & 1 & 221.05 & 17687500 & 7367 & \\
\hline Mobile Skillfulness & 2 & 2 & 257.32 & 18000 & 1.002 & .000 \\
\hline & & 1 & 216.39 & & & \\
\hline & $1 \mathrm{~N}$ & 2 & 263.25 & 10214.000 & -10.020 & .000 \\
\hline & IN1 & 1 & 244.70 & & & \\
\hline & 110 & 2 & 229.52 & 20105.000 & $-1.2+J$ & .215 \\
\hline & IN? & 1 & 257.76 & 23122000 & 3.656 & 000 \\
\hline F4 & 1102 & 2 & 215.84 & 25122.000 & -3.000 & .000 \\
\hline Innovativeness & & 1 & 259.33 & & & \\
\hline & IN3 & 2 & 215.32 & 22151.000 & -3.822 & .000 \\
\hline & IN4 & 1 & 257.02 & 23296.000 & -3.301 & .001 \\
\hline & & 2 & 271.57 & & & \\
\hline
\end{tabular}


Table 6

Mann-Whitney U test (Independent variable: Have you purchased products/ services via mobile devices?; dependent: psychographic m-shopping variables)

\begin{tabular}{|c|c|c|c|c|c|c|}
\hline \multirow[b]{2}{*}{ Variables } & \multirow[b]{2}{*}{ Items } & \multirow[b]{2}{*}{ Group } & \multirow[b]{2}{*}{ Mean Rank } & \multicolumn{3}{|c|}{ Test Statistics } \\
\hline & & & & Mann-Whitney U & $\mathbf{Z}$ & $\begin{array}{l}\text { Asymp. Sig. } \\
\text { (2-tailed) }\end{array}$ \\
\hline \multirow{8}{*}{$\begin{array}{l}\text { F5 } \\
\text { Trust }\end{array}$} & \multirow{2}{*}{ TR1 } & 1 & 203.54 & \multirow{2}{*}{18693.500} & \multirow{2}{*}{-6.409} & \multirow{2}{*}{.000} \\
\hline & & 2 & 279.63 & & & \\
\hline & \multirow{2}{*}{ TR2 } & 1 & 206.32 & \multirow{2}{*}{19429.000} & \multirow{2}{*}{-5.914} & \multirow{2}{*}{.000} \\
\hline & & 2 & 276.09 & & & \\
\hline & \multirow{2}{*}{ TR3 } & 1 & 209.21 & \multirow{2}{*}{20196.500} & \multirow{2}{*}{-5.431} & \multirow{2}{*}{.000} \\
\hline & & 2 & 272.40 & & & \\
\hline & \multirow{2}{*}{ TR4 } & 1 & 199.75 & \multirow{2}{*}{17687.500} & \multirow{2}{*}{-7.362} & \multirow{2}{*}{.000} \\
\hline & & 2 & 284.46 & & & \\
\hline \multirow{6}{*}{$\begin{array}{l}\text { F6 } \\
\text { Perceived Anxiety }\end{array}$} & \multirow{2}{*}{ AN1 } & 1 & 293,06 & \multirow{2}{*}{18693.500} & \multirow{2}{*}{-6.409} & \multirow{2}{*}{.000} \\
\hline & & 2 & 165.58 & & & \\
\hline & \multirow{2}{*}{ AN2 } & 1 & 277.46 & \multirow{2}{*}{19429.000} & \multirow{2}{*}{-5.914} & \multirow{2}{*}{.000} \\
\hline & & 2 & 185.45 & & & \\
\hline & \multirow{2}{*}{ AN3 } & 1 & 282.28 & & & \\
\hline & & 2 & 179.31 & $208 / 8.000$ & $-4.8 / 2$ & .000 \\
\hline & & 1 & 203.68 & & & \\
\hline & I K1 & 2 & 279.45 & 20000.500 & & .000 \\
\hline F6 & DP? & 1 & 214.44 & 21745500 & & \\
\hline Perceived Risk & PKL & 2 & 265.75 & $21 / 45.500$ & -4.502 & .000 \\
\hline & PD? & 1 & 208.50 & 1046750 & & \\
\hline & PKJ & 2 & 208.50 & $1840 / .500$ & -0.483 & .000 \\
\hline & PF1 & 1 & 206.61 & 10505500 & 5712 & 000 \\
\hline & 121 & 2 & 275.72 & (1900000 & -5.112 & .000 \\
\hline F7 & PF2 & 1 & 213.09 & 21233000 & 4404 & 000 \\
\hline Perceived Enjoyment & PEL & 2 & 267.47 & $212 \angle 5.000$ & -4.494 & .000 \\
\hline & $\mathrm{DE} 3$ & 1 & 214.60 & 21602500 & & 000 \\
\hline & PES & 2 & 265.54 & 21025.500 & -4.200 & .000 \\
\hline
\end{tabular}

The above table (Table 6) introduces us to the variables that reveal the psychographic aspects of the users in respect to m-shopping, firstly for the variable of trust (F5). The p-value of all the four items is 0.000 (less than 0.05 ). This means that their mean values differ according to whether the respondent claimed to be an active m-shopping user or not. These results have been confirmed by Hung's (2012) and Groß's research (2014), as well. Respectively, it is evident that the mean value of Group 2 compared to Group 1 is clearly higher, strengthening the factor in relation to transaction security (TR1), protection of personal data (TR2), terms and conditions observance (TR3) and transaction expectations (TR4). Security was also found to be a significant factor in the research of Yang and Forney (2013). 
There is a statistical difference in the perceived anxiety (F6) and Group 2 (active m-shopping users) has higher percentages for the feeling of transaction security and also for the feeling of enjoyment of m-shopping. Hence, Group 2 has a higher mean value.

Table 7

Mann-Whitney U test (Independent variable: Have you purchased products/ services via mobile devices?; dependent: psychographic m-shopping variables)

\begin{tabular}{|c|c|c|c|c|c|c|}
\hline \multirow[b]{2}{*}{ Variables } & \multirow[b]{2}{*}{ Items } & \multirow[b]{2}{*}{ Group } & \multirow[b]{2}{*}{ Mean Rank } & \multicolumn{3}{|c|}{ Test Statistics } \\
\hline & & & & Mann-Whitney U & $\mathbf{Z}$ & $\begin{array}{l}\text { Asymp. Sig. } \\
\text { (2-tailed) }\end{array}$ \\
\hline \multirow{20}{*}{$\begin{array}{l}\text { F8 } \\
\text { Relationship Drivers }\end{array}$} & \multirow{2}{*}{ RD1 } & 1 & 220.00 & \multirow{2}{*}{23054.000} & \multirow{2}{*}{-3.256} & \multirow{2}{*}{.001} \\
\hline & & 2 & 258.66 & & & \\
\hline & \multirow{2}{*}{ RD2 } & 1 & 219.12 & \multirow{2}{*}{22823.000} & \multirow{2}{*}{-3.533} & \multirow{2}{*}{.000} \\
\hline & & 2 & 259.77 & & & \\
\hline & \multirow{2}{*}{ RD3 } & 1 & 219.93 & \multirow{2}{*}{23036.500} & \multirow{2}{*}{-3.380} & \multirow{2}{*}{.001} \\
\hline & & 2 & 258.75 & & & \\
\hline & \multirow{2}{*}{ RD4 } & 1 & 230.10 & \multirow{2}{*}{25732.500} & \multirow{2}{*}{-1.288} & \multirow{2}{*}{.198} \\
\hline & & 2 & 245.79 & & & \\
\hline & \multirow{2}{*}{ RD5 } & 1 & 199.73 & \multirow{2}{*}{17683.000} & \multirow{2}{*}{-7.207} & \multirow{2}{*}{.000} \\
\hline & & 2 & 284.49 & & & \\
\hline & \multirow{2}{*}{ RD6 } & 1 & 198.20 & \multirow{2}{*}{17278.500} & 7454 & 000 \\
\hline & & 2 & 286.43 & & $-1.4 J 4$ & .000 \\
\hline & & 1 & 179.74 & & & \\
\hline & IN) & 2 & 309.95 & $1250 \%$ & -10 & .000 \\
\hline & & 1 & 216.58 & & & \\
\hline & 100 & 2 & 263.02 & 251800 & 5.8 & 1000 \\
\hline & & 1 & 214.20 & & & \\
\hline & 10) & 2 & 266.05 & 21018 & & .000 \\
\hline & & 1 & 208.14 & 10011000 & & 000 \\
\hline & (1010 & 2 & 273.77 & 19811.000 & דלד. & .000 \\
\hline & & 1 & 192.74 & & & \\
\hline & & 2 & 293.93 & & & \\
\hline & RI2 & 1 & 210.13 & 20440000 & & 000 \\
\hline F9 & Diz & 2 & 271.23 & $20+40.000$ & -3.100 & .000 \\
\hline Behavioral Intention & & 1 & 203.46 & & & \\
\hline & В13 & 2 & 279.73 & $180 / 3.000$ & -0 & .000 \\
\hline & & 1 & 194.42 & & & 000 \\
\hline & D14 & 2 & 291.25 & 10213.000 & & .000 \\
\hline & CN1 & 1 & 223.44 & 29067500 & & 010 \\
\hline & Nivi & 2 & 254.27 & $2590 \% .000$ & & .010 \\
\hline F10 & & 1 & 218.04 & & & \\
\hline Subjective Norm & & 2 & 261.16 & 20051.000 & 5.070 & \\
\hline & $\mathrm{CN} 2$ & 1 & 220.82 & מ 502327 & & $00 ?$ \\
\hline & SIV & 2 & 257.61 & 25212.500 & -5.001 & .002 \\
\hline
\end{tabular}


According to Table 7, the p-value for almost all the items of the variable of trust building through motives (F8) is 0.000 (less than 0.05), apart from item RD4 (location notifications), which does not statistically differ for the groups in question. Respectively, the mean positions of experienced m-shopping users are apparently higher compared to the rest of the sample, thus adding further value to the m-shopping motives (such as reward with loyalty points, redemption of coupons and value of m-shopping). These facts seem to confirm studies conducted by Drossos et al. (2014), Ha and Im (2014), and Khajehzadeh et al. (2014).

Finally, social influence (F9) and attitude towards m-shopping (F10) show great statistical differences. More precisely, adopters of $\mathrm{m}$-shopping have a higher mean position and thus they are more influenced by their surroundings to adopt m-shopping. It is expected then that they tend to react positively to the idea of further development of m-shopping. These variables improve findings of existing studies in m-shopping (Zhong, 2012; Ferri et al., 2013).

\section{DISCUSSION AND CONCLUSION}

Based on Mann-Whitney test and descriptive statistics, this paper reached several conclusions regarding the variable items for $\mathrm{m}$-shopping and more specifically the current experience of the respondents in m-shopping. Our approach is based on the differences that emerged from our groups of Greek shoppers (adopters versus non-adopters) and leads to characteristics that could be considered in a consumer-based study that examines the m-shopping behavior.

\subsection{Theoretical and Managerial Implications}

As far as the technical aspects are concerned, the users having experience in mobile markets adopt a more comprehensive and positive attitude towards the items for the ease of use and usefulness, such as convenience and use of mobile phones to search for products/services. They moderately agree $(24.5 \%)$ on usability and efficacy issues of mobile markets. This particular correlation is confirmed by research conducted by Groß (2014), Wang et al. (2015), Lu (2014) and Chen (2012). Having analyzed the measurements, it can be argued that active m-shoppers are the ones to exhibit a sense of certainty and self-confidence about m-shopping activities. Regarding the issue of being a step ahead in the adoption of new technologies, m-shoppers seem to be quite zealous (40\%) in comparison with the potential users, half of whom clearly disagreed. Both groups agreed on the importance of experimenting and getting updated about the emergence of new technologies. Group 2, however, showed a stronger enthusiasm with a percentage that exceeds $50 \%$.

In respect to the psychographic and social aspects of $m$-shopping, many inactive $m$-shopping users $(39.6 \%)$ - compared to the rest $(12 \%)$ - are afraid of making a mistake during $\mathrm{m}$-shopping processes (Yang and Forney, 2013). The sense of perceived danger is directly connected to the experience of a Greek mobile shopper (Chen and Yang, 2012; Özer et al., 2013). The research shows that almost $50 \%$ of both groups are highly skeptical regarding security issues in m-shopping. Active m-shopping users, though, appear to attribute more credibility to the security provided by e-shops (41.3\%). In addition, $41 \%$ of active $\mathrm{m}$-shoppers appreciate the enjoyment and pleasure of m-shopping; in contrast to the potential users who express a clear concern (34.7\%).

In spite of the fact that there is a statistical difference between the 2 groups concerning their motives to m-shop - this relation is supported by the extensive research carried out by Khajehzadeh et al. (2014) - there is a general disagreement in percentages, which exceed $80 \%$, on the issue of m-shopping adoption as an integral part of daily life. These percentages hold for those who have no experience in m-shopping. It is impressive at the same time that if we disregard a few signs of moderation on the part of active $m$-shoppers, this group does not attribute 
the expected value to $\mathrm{m}$-shopping. This is proven by the fact that more than $60 \%$ of them do not consider that the idea of m-shopping reflects the elements of their personality. Nevertheless, both groups are attracted by rewards with loyalty points (34\%). In respect to the social influence that users receive from their environment, non-experienced m-shopping users unanimously $(>80 \%)$ state that people around them do not try to persuade them to m-shop because they do not prefer $\mathrm{m}$-shopping themselves either. What is paradoxical, though, is that the aforementioned belief is also shared by $50 \%$ of experienced m-shopping users, with very few signs of moderation. The illustration of the correlation between social influence and m-shopping presented in this research is somehow similar to other research (e.g., San-Martín et al., 2015; Ferri et al., 2013; Yang, 2012; Yang, 2010).

The main statistical difference recorded is the positive influence of adopters of m-shopping in respect to $\mathrm{m}$-shopping adoption, a result which deviates from the other researchers' findings (Kumar and Mukherjee, 2013). However, there is an expressed moderation on the part of potential users concerning the possibility of engaging in m-shopping in the future (44.9\%). There is also a definite exclusion of the possibility of engaging in $\mathrm{m}$-shopping systematically (36\%). Under the light of the above findings, it is no wonder that potential users are reluctant to promote $\mathrm{m}$-shopping to the people in their surroundings $(39 \%)$. Active users seem to be more positively predisposed in relation to the aforementioned findings, with their percentage not exceeding $48 \%$. According to the results, active Greek m-shopping users are those who exhibit a positive behavior of the variable as the majority of them have a positive attitude towards the philosophy of m-shopping $(63.9 \%)$ and they think it is a clever idea (57.2\%). The other half of the sample $(53.6 \%)$ agrees on the fact that m-shopping is a good and clever idea but is unable to keep a purely positive attitude $(41.5 \%)$, because they cannot comprehend the difference between the mobile channel and other alternative.

\subsection{Suggestions, Limitations and Future Work}

Firstly, the design of a credible environment for the services of mobile devices which will generate reliable information for the market should be based on the interests, preferences and needs of the customer, so that potential users may attribute value to the latter. Mobile providers should offer personalized shopping environments, based on their customers' specific needs. This need is apparently associated with the fact that future $\mathrm{m}$-shoppers perceive the dimension that is related with the sense of being in a store as very important.

Another crucial success factor for virtual mobile retailing is the provision of alternative payment methods. The fact that both current and future Greek m-shoppers focus on cash on delivery as the most desired payment method (Vrechopoulos et al., 2001), probably due to security factors and psychological ones as well, which are derived from the findings that are related with specific variables (Perceived Risk, Anxiety), shows that they may use this as a choice criterion. Thus, the provision of this alternative payment method is surely recommended for virtual mobile retailers.

The findings of the study suggest that m-shopping system quality, as well as information and service quality, seems to have the power to affect the mobile user willingness and capability that leads to a continuance intention toward m-commerce.

It is significant that a reliable mechanism of transaction which provides a reliable and secure experience of sales may be perceivable at any moment and at any place through the use of smartphones. With technology enabled, it is more than obvious that the application and m-shopping should be more closely monitored by mobile providers through consumer surveys.

Likewise, m-providers should focus on the benefits of m-shopping through advertising campaigns concentrating on how time and money savings can be achieved and how to facilitate the buying process, so that the m-shopping intention may increase. M-coupons is another way 
to attract the audience, taking into consideration the simplification of their exchange (e.g. direct reduction of the price instead of a reduction offered for the next purchase), a fact that would contribute with clear positive attributes to m-shopping engagement.

We also suggest that companies that are determined to conduct mobile phone sales should be aware that satisfaction seems to be a crucial factor for the attraction of potential buyers in this type of market, which validates the findings of other studies conducted both offline and online (Akroush et al., 2011). M-vendors should create a climate which benefits the adoption of new technologies by Greek customers through participating in communication campaigns which promote the recreation of consumers during the usage of their mobile phones for buying purposes, as it is of vital importance to offer satisfaction which enhances the trend towards m-shopping activities. Pertaining to entertainment and recreation, software providers should design webpages compatible with mobile phone formats and prerequisites, including elements of interaction, images and videos during the navigation for buying (virtual reality), so that the social aspect of navigation may be ameliorated (Goel et al., 2013). Greek customers without experience in m-shopping may be prone to evaluations and suggestions of the keen ones as far as mobile phone shopping is concerned, so that they may support their decision. For this reason, retailers should look into witness statements and comments of their clients/customers on m-shopping as an advertising tool which may convey a message, which could lead to the intention for $\mathrm{m}$-shopping through customer satisfaction. The limitations of the present research pertain to a sample collected in the context of a given country (Greece). Regarding the methodology adopted for this paper, there has been a correlation between one independent variable (m-shopping experience) and other variables. Consequently, all the potential correlations which could possibly lead to alternative findings are not covered. Finally, as far as further research is concerned, we believe that it would be interesting to compare this m-shopping approach in different countries with different levels of financial and technological advancement. A future study could serve for the analysis of potential findings for the maintenance of the participation in m-shopping, the experience or the income. With all the signs indicating further growth and wider dissemination among m-shopping users and buyers, it would be interesting to repeat the research, considering new critical factors that may emerge. Likewise, this repetition could occur when successful or unsuccessful strategies of innovative m-shopping strategies become widely known. Finally, a multi-channeled model could be proposed, including mobile telephony, the internet and offline shops as different but complementary channels for shopping activities.

\section{References}

Akroush, M.N., Al Mohammad, S.M., Zuriekat, M.I. and Algul-Lail, B.N. (2011). An empirical model of customer loyalty in the Jordanian mobile telecommunications market. International Journal of Mobile Communications, $9(1), 76-101$.

Chen, Y.Y. (2012). Why do consumers go internet shopping again? Understanding the antecedents of repurchase intention. Journal of Organizational Computing and Electronic Commerce, 22(1), 38-63.

Chen, L.Y. (2013). The quality of mobile shopping system and its impact on purchase intention and performance. International Journal of Managing Information Technology, 5(2), 23-32.

Chen, L.S. and Yang, Y.Y. (2012). Identifying key factors for increasing royalty of customers in mobile shopping services. Proceedings of the International Multi-Conference of Engineers and Computer Scientists, Vol. 1, 492-496. Hongkong.

Clarke, I. and Flaherty, T.B. (2003). Web-based B2B portals. Industrial Marketing Management, 32, 15-23.

Clarke III, I. (2008). Emerging value propositions for m-commerce. Journal of Business Strategies, 25(2).

Dillman, D. (2007) Mail and internet surveys: The tailored designed method, second ed. Hoboken, New Jersey: John Wiley and Sons Inc.

Drossos, D., Kokkinaki, F., Giaglis, G. and Fouskas, K. (2014). The effects of product involvement and impulse buying on purchase intentions in mobile text advertising. Electronic Commerce Research and Applications, $13,423-430$. 
Duquenne, M.N. and Vlontzos, G. (2014). The impact of the Greek crisis on the consumers' behaviour: Some initial evidences? British Food Journal, 116(6), 890-903.

Fenech, T. (2002). Exploratory study into wireless application protocol shopping. International Journal of Retail and Distribution Management, 30(10), 482-497.

Ferri, F., Grifoni, P. and Guzzo, T. (2013). Factors Determining mobile shopping. A theoretical model of mobile commerce acceptance. International Journal of Information Processing and Management, 4(7), 89-101.

Gehrt, K. and Carter, K. (1992). An exploratory assessment of catalog shopping orientation: The existence of convenience and recreational segment. Journal of Retailing, 6(1), 29-39.

Goel, L., Johnson, N., Junglas I. and Ives, B. (2013). Predicting users' return to virtual worlds: A social perspective. Information Systems Journal, 23, 35-63.

Groß, M. (2014). Exploring the acceptance of technology for mobile shopping: an empirical investigation among smartphone users. The International Review of Retail, Distribution and Consumer Research, 23(3), 215-235.

Groß, M. (2015). Mobile shopping: A classification framework and literature review. International Journal of Retail and Distribution Management, 43(3), 221-241.

Ha, Y. and Im, H. (2014). Determinants of mobile coupon service adoption: Assessment of gender difference. International Journal of Retail and Distribution Management, 42(5), 441-459.

Holmes, A., Byrne, A. and Rowley, J. (2013). Mobile shopping behaviour: Insights into attitudes, shopping process involvement and location. International Journal of Retail and Distribution Management, 42(1), 25-39.

Hung, M.C., Yang, S.T. and Hsieh, T.C. (2012). An examination of the determinants of mobile shopping continuance. International Journal of Electronic Business Management, 10(1), 29-37.

Jih, W.J.K. and Lee, S.F. (2003). An exploratory analysis of relationships between cellular phone uses' shopping motivators and lifestyle indicators. Journal of Computer Information Systems, 44(2), 65-73.

Karaatli, G., Ma, J. and Suntornpithug, N. (2010). Investigating mobile services' impact on consumer shopping experience and consumer decision-making. International Journal of Mobile Marketing, 5(2), 75-86.

Khajehzadeh, S., Oppewal, H. and Tojib, D. (2014). Consumer responses to mobile coupons: The roles of shopping motivation and regulatory fit. Journal of Business Research, 67(11), 2447-2455.

Kearny, J. (2010). Food consumption trends and drivers. Philosophical transactions of Royal Society B, 365 , 2793-2807.

Ko, E., Kim, E.Y. and Lee, E.K. (2009). Modeling consumer adoption of mobile shopping for fashion products in Korea. Psychology and Marketing, 26(7), 669-687.

Kotler, P. (1994). Marketing management - analysis, planning, implementations, and control. Englewood Cliffs: Prentice-Hall Inc.

Kumar, A. and Mukherjee, A. (2013). Shop while you talk: Determinants of purchase intentions through a mobile device. International Journal of Mobile Marketing, 8(1), 23-37.

Lee, H.H. and Kim, J. (2010). Investigating dimensionality of multichannel retailer's cross-channel integration practice and effectiveness: Shopping orientation and loyalty intention. Journal of Marketing Channels, 17(4), 281-312.

Lee, H. and Lee, S. (2010). Internet vs mobile services: Comparisons of gender and ethnicity. Journal of Research in Interactive Marketing, 4(4), 346-374.

Levy, Y. and Ellis, T.J. (2006). A systems approach to conduct an effective literature review in support of information systems research. Informing Science Journal, 9, 181-212.

Lim, H., Widdows, R. and Park, J. (2006). M-loyalty: Winning strategies for mobile carriers. Journal of Consumer Marketing, 23(4), 208-218.

Lu, J. (2014). Are personal innovativeness and social influence critical to continue with mobile commerce? Internet Research, 24(2), 134-159.

Michalopoulos, V.G., and Dimoussis, M.P. (2001). Greek household consumption of food away from home: A mocroeconometric approach. European Review of Agricultural Economics, 28, 421-432.

Nielsen (2013). The mobile consumer: A global snapshot. Retrieved on 27.04.2014 from http://www.nielsen.com/ content/dam/corporate/us/en/reportsdownloads/2013\%20Reports/Mobile-Consumer-Report-2013.pdf.

Özer, A., Argan, M.T. and Argan, M. (2013). The effect of mobile service quality dimensions on customer satisfaction. Procedia-Social and Behavioral Sciences, 99(6), 428-438.

Papafotikas, I., Chatzoudes, D. and Kamenidou, I. (2014). Purchase decisions of Greek customers: An empirical study. Procedia Economics and Finance, 9, 456-465.

San-Martín, S., López-Catalán, B. and Ramón-Jerónimo, M.A. (2013). Mobile shoppers: Types, drivers, and impediments. Journal of Organizational Computing and Electronic Commerce, 23(4), 350-371.

San-Martín, S., Prodanova, J. and Jiménez, N. (2015). The impact of age in the generation of satisfaction and WOM in mobile shopping. Journal of Retailing and Consumer Services, 23, 1-8.

Scoop Media. (2013). Smartphone adoption driving mobile shopping habits. Retrieved on 27.04.2014 from http:// www.scoop.co.nz/stories/BU1304/S00321/smartphone-adoprtion-driving-mobile-shopping-habits.thm. 
Statista (2017a). Digital coupons and deals - Statistics \& Facts. Retrieved on 12.11.2017 from https://www.statista. com/topics/2162/digital-coupons-and-deals.

Statista. (2017b). Mobile Internet - Statistics \& Facts. Retrieved on 12.11.2017 from https://www.statista.com/ topics/779/mobile-internet.

Statista. (2017c). Reasons for mobile shoppers to purchase products via smartphone or tablet as of August 2016, by region. Retrieved on 12.11.2017 from https:/www.statista.com/statistics/614708/ mobile-smartphone-and-tablet-shopping-reasons-region.

Tilikidou, I. and Delistavrou, A. (2014). Pro-environmental purchasing behaviour during the economic crisis. Marketing Intelligence \& Planning, 32(2), 160-173.

Tsourgiannis, L. (2008). The marketing strategies of livestock enterprises in objective one regions: A comparative study between Greece and United Kingdom. PhD Thesis. University of Plymouth.

Tsourgiannis, L., Karassavoglou, A. Tsourgiannis, C.A. Florou, G., Theodosiou, T. and Valsamidis, S. (2014). Factors affecting consumers in Greece to buy during economic crisis period food produced domestically in Greece. Procedia Economics and Finance, 29, 439-455.

Varnali, K. and Toker, A. (2010). Mobile marketing research: The-state-of-the-art. International Journal of Information Management, 30(2), 144-151.

Vlamis, P. (2014). Greek fiscal crisis and repercussions for the property market. Journal of Property Investment \& Finance, 32(1), 21-34.

Vrechopoulos, A., Siomkos, G. and Doukidis G. (2001). Internet shopping adoption by Greek consumers. European Journal of Innovation Management, 4(3), 142-153.

Wang, R.J.H., Malthouse, E.C. and Krishnamurthi, L. (2015). On the go: How mobile shopping affects customer purchase behavior. Journal of Retailing, 91(2), 217-234.

Wong, C.H., Lee, H.S., Lim, Y.H., Chua, B.H. and Tan, G.W.H. (2012). Predicting the consumers' intention to adopt mobile shopping: An emerging market perspective. International Journal of Network and Mobile Technologies, 3(3), 24-39.

Wu, J.H. and Wang, Y.M. (2006). Development of a tool for selecting mobile shopping site: A customer perspective. Electronic Commerce Research and Applications, 5(4), 192-200.

Yang, K. (2010). Determinants of US consumer mobile shopping services adoption: Implications for designing mobile shopping services. Journal of Consumer Marketing, 27(3), 262-270.

Yang, K. (2012). Consumer technology traits in determining mobile shopping adoption: An application of the extended theory of planned behavior. Journal of Retailing and Consumer Services, 19(5), 484-491.

Yang, K. and Forney, J.C. (2013). The moderating role of consumer technology anxiety in mobile shopping adoption: Differential effects of facilitating conditions and social influences. Journal of Electronic Commerce Research, 14(4), 334-347.

Yang, S., Wang, Y. and Wei, J. (2014). Integration and consistency between web and mobile services. Industrial Management and Data Systems, 114(8), 1246-1269.

Zhong, C. (2013). Critical factor analysis of mobile online shopping adoption: from mobile phone users' perspectives. International Conference on Computational and Information Sciences (pp. 1668-1670). Shiyan, Hubai, China. 